\title{
Assessment of the Transoral Maxillectomy
}

\author{
MOHAMMAD W. EL-ANWAR, M.D.; MAGDY A. SAYED EL-AHL, M.D.; HAZEM S. AMER, M.D. and \\ MOHAMED A. AL SHAWADFY, M.D. \\ The Department of Otolaryngology, Head and Neck Surgery, Faculty of Medicine, Zagazig University, Egypt
}

\begin{abstract}
Background: Head and neck cancer accounts for $17 \%$ of all cancer cases and could affect functions such as swallowing, phonation, breathing, aesthetics and the individual's quality of life.

Aim of Study: To assess the transoral approach for maxillectomy in selected cases of cancer maxilla.

Patients and Methods: The study included patients who were diagnosed to have maxillary carcinoma after the endoscopic biopsy. The transoral approach was used for maxillectomy in all cases. Then, the patients were followed-up for 5 years.

Results: Within the included eleven patients with maxillary squamous cell carcinoma, transoral maxillectomy could be performed without the need for any skin incision. No uncontrollable epistaxis, orbital injury, septal perforation, postoperative fistula, skin necrosis, vestibular stenosis or granulation was observed. Recurrence of the tumor was detected in one case only $(9.1 \%)$ throughout the follow-up.

Conclusion: The transoal approach for maxillectomy can be considered as a reliable and safe approach for selected cases of cancer maxilla. So, it should be incorporated into the oncological and maxillofacial surgeon's surgical armamentarium to avoid external incisions.
\end{abstract}

Key Words: Transoral maxillectomy - Maxillectomy-Maxillary sinus - Cancer maxilla.

\section{Introduction}

HEAD and neck cancer accounts for $17 \%$ of all cancer cases and could affect functions such as swallowing, phonation, breathing, aesthetics and the individual's quality of life [1].

Total and subtotal maxillectomies are performed to resect malignant tumors of the maxilla. The techniques of maxillectomy have changed considerably since the procedure was first performed by Lizars in 1826 [2].

Correspondence to: Dr. Mohammad W. El-Anwar, The Department of Otolaryngology, Head and Neck Surgery, Faculty of Medicine, Zagazig University, Egypt
Many surgical approaches have been developed for resection of the maxilla, including lateral rhinotomy and midfacial degloving procedures [3-5] those are traditionally performed for total and subtotal maxillectomy.

Lateral rhinotomy can provide good exposure of the tumor to the pyriform aperture, but this approach leaves an obvious facial scar. Furthermore, if the patient received radiation therapy, it is possible to cause a facial fistula as a result of insufficiently vascularized soft tissues.

One of the advantages of the midfacial degloving approach is the avoidance of facial incision, so cosmetic outcomes are better. However, sometimes it is difficult to expose the frontal process of the maxilla. It also requires transfixion of the nasal septum, and therefore carries the risk of vestibular stenosis [6].

Trans-oral maxillectomy requires no facial incision and reduces deformity, thereby decreasing the psychological trauma of that radical surgery [7]. However, it was not popularized and was sparsely studied in the literature.

In the current study, we assess the transoral approach for total maxillectomy.

\section{Patients and Methods}

This prospective study was conducted in the Department of Otorhinolaryngology Head and Neck Surgery, Zagazig University Hospitals over the period from October 2012 to September 2014. The study was approved by the Institutional Review Board (IRB) at Zagazig University Hospitals. Informed consent was obtained from all study subjects who were recruited at the outpatient clinic after explanation of the research purpose. 
This study included eleven patients ( 9 males and 2 females) with age ranging from 49 to 68 years who were diagnosed to have maxillary carcinoma. Diagnosis was based on history taking, clinical examination including edoscopic examination of the nose and preoperative biopsy for histipathological examination to ensure the malignant nature of the sinus disease.

Enhanced computed tomography (CT); coronal and axial cuts, were performed for every case to evaluate and ascertain the extent of the lesion. Magnetic Resonance Imaging (MRI) was not indicated in the patients of this study as no skull base erosion or orbital invasion was detected while doing CT scan.

Preoperatively, all patients were examined by prosthodontist and design an optimal prosthesis (soft acrylic) which is actually a temporary one. This was fixed immediately after surgery. Final prosthesis was fitted after the completion of treatment which included irradiation and/or chemotherapy.

Ophthalmic examination helped in ruling out ocular involvement and because the orbit was not involved, orbital exenteration was not needed.

Inclusion criteria patients have maxillary cancer limited to maxillary sinus indicated and scheduled for maxillectomy.

Exclusion criteria: Patient has orbital or intracranial extension, lesion extends to facial soft tissue, skin or sublabial mucosa, previously operated patient by external approach, unfit for surgery.

\section{Staging of cancer maxilla:}

In this study staging of cancer maxilla was done according to the American Joint Committee on Cancer (AJCC) 2010 [8]

- T1: Tumor limited to maxillary sinus mucosa with no erosion or destruction of bone.

- T2: Tumor causing bone erosion or destruction including extension into the hard palate and/or middle nasal meatus, except extension to posterior wall of maxillary sinus and pterygoid plates.

- T3: Tumor invades any of the following: Bone of the posterior wall of maxillary sinus, subcutaneous tissues, floor or medial wall of orbit, pterygoid fossa, or ethmoid sinuses.

- T4a: Moderately advanced local disease.

Tumor invades anterior orbital contents, skin of cheek, pterygoid plates, infratemporal fossa, cribriform plate, or sphenoid or frontal sinuses.

- T4b: Very advanced local disease.
Tumor invades any of the following: Orbital apex, dura, brain, middle cranial fossa, cranial nerves other than maxillary division of trigeminal nerve $\left(V_{2}\right)$, nasopharynx, or clivus.

\section{Procedure:}

This surgery was performed under general anesthesia with oral endotracheal intubation and patient was in the supine position. Tarsorraphy was performed on the side of lesion.

Transoral approach was used in this study. Before doing the incision, the mucosa of the pyriform aperture and the labiogingival groove at both sides was infiltrated with using adrenaline dissolved in saline at a concentration of 1: 200000 for local hemostasis.

Then incision was made about $5 \mathrm{~mm}$ above the gingivobuccal sulcus, starting from the contralateral first molar to the third ipsilateral molar. Blunt subperiosteal dissection of the soft tissues was performed with a freer dissector along the anterior wall of the ipsilateral maxillary sinus in the subperiosteal plane, until the ipsilateral infraorbital rim was located superiorly and the zygomaticomaxillary fissure was located laterally. Superiorly, the infraorbital neurovascular bundle was identified and ipsilateral infraorbital nerve was sacrificed after taking a biopsy from it to rule out perineural invasion.

Three points needed to be exposed clearly using a retractor. First, the facial soft tissue had to be fully retracted superiorly up to the level of the medial canthus to expose and cut the frontal process of the maxilla. This was facilitated by elevation of the nasal vestibule. The second was the zygomaticomaxillary fissure, which had to be cut off vertically. Sometimes it could be difficult to locate the zygomaticomaxillary fissure during the operation. In such cases, osteotomy was performed vertically along a line $2 \mathrm{~cm}$ lateral to the infraorbital aperture. This was easily reached by retraction due to extension of sublabial incision to contralateral first molar tooth and vestibular elevation. A third incision was then made sagittally along the hard palate with a giggle saw, from posterior to anterior. For optimum results, this osteotomy should be performed as close as possible to the medial maxillary wall to preserve more palatal bone, if it is not involved by the lesion. Finally, maxillectomy was completed in the standard way. Before wound closure, 0 and 30 degree $4 \mathrm{~mm}$ diameter endoscopes were used to visualize and reevaluate the operative field for any tumor remnant and to assure complete hemostasis. 
Following resection of the maxilla, the facial soft tissue was returned to the normal position. The preoperatively prepared temporary obturator was fixed for immediate temporary prosthetic reconstruction of the hard palatal defect.

Immediate reconstruction by soft acrylic was done to prevent skin contracture and mimic shape and help packing.

Anterior nasal pack was done and it was removed 48 hours after surgery, postoperative antibiotics and anti-inflammatory drugs were prescribed to guard against infection and to relieve edema which occurred postoperatively. Then, the patients were followed-up daily for one week, then weekly for one month, then monthly for six months then annually for 5 years. In each follow-up set, nasal endoscopy was performed.

\section{Results}

This study included eleven patients (9 males and 2 females). Their ages ranged from 49 to 68 years with a mean age of $59.45 \pm 5$ years.

Histopathological results of preoperative biopsies obtained from patient showed maxillary squamous cell carcinoma with free surgical margins in all included patients.

The eleven patients underwent total maxillectomy via transoral approach with no need for any external incisions. This was followed immediately by reconstruction using the previously prepared soft acrylic prosthesis which was well tolerated by patients who showed no significant feeding or speech difficulties postoperatively.

No intraoperative or postoperative mortality was recorded among the eleven patients. Blood loss during surgery was acceptable. Facial edema was reported in the elven patients, but no ecchymosis was recorded in any of the cases. Facial edema subsided within one to two weeks after surgery.

The postoperative hospitalization period was variable from one patient to another with a mean period of 8 days. Postoperative nasal crustation was recorded nearly in all cases which improved within a month. But no uncontrollable epistaxis, orbital injury, septal perforation, postoperative fistula, skin necrosis, vestibular stenosis or granulation was observed.

The cosmetic results were generally was accepted by all patients. None of the patients included in this work received postoperative radiotherapy as the surgical margin of resection was free of tumor cells after all postoperative pathological examination.

The follow-up nasal endoscopy and CT scan of the nose and paranasal sinuses showed recurrence of the tumor in one patient only $(9.1 \%)$ (Table 1$)$.

Table (1): Patients' data.

\begin{tabular}{|c|c|c|c|c|c|c|c|}
\hline Patient & $\begin{array}{l}\text { Age in } \\
\text { years }\end{array}$ & Sex & Site of tumor & $\begin{array}{l}\text { Stage of } \\
\text { tumor }\end{array}$ & Recurrence & $\begin{array}{l}\text { Permanent } \\
\text { complication }\end{array}$ & $\begin{array}{l}\text { Cosmetic } \\
\text { results }\end{array}$ \\
\hline $1-$ & 63 & M & Lt maxillary sinus, Lt nasal cavity & $\mathrm{T} 2$ & No & No & Good \\
\hline $2-$ & 49 & M & Rt maxillary sinus, Rt ethmoid sinus & $\mathrm{T} 3$ & No & No & Good \\
\hline $3-$ & 57 & M & Rt maxillary sinus, Rt nasal cavity & $\mathrm{T} 2$ & No & No & Good \\
\hline 4- & 60 & M & Lt maxillary sinus, Lt nasal cavity & $\mathrm{T} 2$ & No & No & Good \\
\hline $5-$ & 61 & M & $\begin{array}{l}\text { Lt maxillary sinus, Lt nasal cavity } \\
\text { Lt etmoid \& Lt sphenoid sinus }\end{array}$ & $\mathrm{T} 4 \mathrm{a}$ & No & No & $\begin{array}{l}\text { Fair } \\
\text { Accept(ed) }\end{array}$ \\
\hline $6-$ & 55 & $\mathrm{~F}$ & $\begin{array}{l}\text { Rt. maxillary sinus, Rt. Nasal cavity, } \\
\text { Rt. hard palate }\end{array}$ & $\mathrm{T} 2$ & No & No & Good \\
\hline 7- & 64 & M & $\begin{array}{l}\text { Rt maxillary sinus. } \\
\text { Rt nasal cavity }\end{array}$ & $\mathrm{T} 2$ & No & No & Good \\
\hline $8-$ & 61 & M & $\begin{array}{l}\text { Lt maxillary sinus, Lt nasal cavity, } \\
\text { Lt ethmoid sinus }\end{array}$ & $\mathrm{T} 3$ & No & No & Good \\
\hline 9- & 59 & $\mathrm{~F}$ & $\begin{array}{l}\text { Lt maxillary sinus, Lt nasal cavity } \\
\text { Lt ethmoid \& shenoid sinuses }\end{array}$ & $\mathrm{T} 4 \mathrm{a}$ & Yes & No & Good \\
\hline $10-$ & 68 & M & $\begin{array}{l}\text { Rt maxillary sinus, Rt nasal cavity, } \\
\text { Rt ethmoid }\end{array}$ & $\mathrm{T} 3$ & No & No & Good \\
\hline $11-$ & 57 & M & Lt maxillary sinus, Lt nasal cavity & $\mathrm{T} 2$ & No & No & Good \\
\hline Mean & $59.45 \pm 5$ & $\begin{array}{l}9 \mathrm{M} \\
2 \mathrm{~F}\end{array}$ & $\begin{array}{l}11 \text { maxillary sinus, } 10 \text { nasal cavity } \\
5 \text { ethmoid sinus, } 2 \text { sphenoid sinus } \\
1 \text { hard palate }\end{array}$ & $\begin{array}{l}5 \mathrm{~T} 2,4 \mathrm{~T} 3, \\
2 \mathrm{~T} 4 \mathrm{a}\end{array}$ & $\begin{array}{l}\text { One } \\
\text { recurrence } \\
(9.1 \%)\end{array}$ & $\begin{array}{l}\text { No reported } \\
\text { Complications }\end{array}$ & $\begin{array}{l}9 \text { Good } \\
2 \text { Fair }\end{array}$ \\
\hline
\end{tabular}




\section{Discussion}

Treatment of the patient with cancers of the maxilla and hard palate is complex and results in significant functional and aesthetic sequelae that include collapse of cheek and infraorbital soft tissues, orbital complications, loss of hemi palate and oral phase of deglutition, and difficulty with articulation and [9]

The techniques of sinusectomy have been changed dramatically since the first maxillectomy was performed by Lizars in 1826 [10]. A mark in the maxillectomy development was attributed to Weber-Fergusson (1845) who described the classic procedure currently used [11]. In the way to preserve as much as possible of the functional tissue integrity, midface degloving procedure was introduced [12]. A facial degloving procedure was first suggested by Portmann in 1927, but the modern technique had its origin in 1974 with the report of Casson et al. [13]. Conley and Pirce first proposed the use of the midfacial degloving procedure for excision of neoplastic diseases in 1979 [14]. Later, Maniglia [15] popularized this technique as an approach for resection of benign and malignant tumors in the paranasal sinuses $[\mathbf{1 5 , 1 6 ]}$.

In the current study, maxillectomy was perfumed through transoral approach avoiding the complications of extraoral approaches (WeberFergusson, Dieffenbach, or lateral rhinotomy) such as facial scars, epiphora and disfigurement of the face such as upward contracture of the alae and deviation of the nose, asymmetry of the upper lip and nasolabial groove, and medial canthal deformity [17].

Transoral approach allows good exposure of the surgical field which may result in proper tumor resection without skin incisions. This approach provides aesthetically pleasing outcomes, leaving no visible scars and virtually no functional disability, with a low complication rate.

In this study, the goal of surgery was achieved to large extent in addition to good aesthetic and functional outcome with low complication rate as by reviewing the complications of surgery using transoral approach, it has been found that, no mortality was recorded either intraoperative or postoperative, no uncontrollable epistaxis, orbital injury, septal perforation, fistula, skin necrosis, vestibular stenosis or granulation were observed.

The results of the current study is consistent to great extent with the study of Liu et al., [18] taking in consideration that they used combined transoral and endoscopic approaches for resection of maxilla. Current study also agree with the study of Kawata [7].

However, the use of this procedure was limited by its technical difficulty and the limited exposure of the infratemporal fossa and, ptrygoplatine fossa, and therefore was not suitable for those patients who have tumor extension to these areas. It is also not suitable for those with tumors extending to the orbit or with intracranial extension.

This study gives an interest for the post tumor resection aesthetic and functional outcome. This agree with the opinion of Adisman et al., [19] who stated that curing the cancer should not be permitted to obscure the importance of the patient's quality of life and post treatment anatomic, physiologic, and psychological impact on the patient. In addition curved instruments mainly curved osteotome are important to facilitate the transoral maxillectomy.

\section{Conclusion:}

The transoal approach for maxillectomy can be considered as an efficient, useful, and safe approach for selected cases of cancer maxilla. It should be incorporated into the oncological and maxillofacial surgeon's surgical armamentarium to avoid external incisions.

\section{References}

1- TORRES T.J.F., JIMÉNEZ C.R. and BERNAL A.R. Hybrid prostheses in total maxillectomy. Revista Odontológica Mexicana, 15 (2): 120-123, 2011.

2- SISSON G.A. Sr., TORIUMI D.M. and ATIYAH R.A.: Paranasal sinus malignancy: A comprehensive update. Laryngoscope, 99 (2): 143-150, 1989.

3- WORMALD P.J., OOI E., VAN HASSELT C.A. and NAIR S.: Endoscopic removal of sinonasal inverted papilloma including endoscopic medial maxillectomy. Laryngoscope, 113 (5): 867-873, 2003

4- SADEGHI N., AL-DHAHRI S. and MANOUKIAN J.J.: Transnasal endoscopic medial maxillectomy for inverting papilloma. Laryngoscope,113 (4): 749-753, 2003.

5- MAHMOUD A.M., SAID A., EL-DESSOUKY I. and SWEED A.H.: Tips and tricks in surgical management of maxillary sinus tomors. EGYNTAS, 18: 43-48, 2017.

6- RAMAKRISHNAN V.R., SUH J.D., CHIU A.G. and PALMER J.N.: Septal dislocation for endoscopic access of the anterolateral maxillary sinus and infratemporal fossa. Am J Rhinol Allergy, 25 (2): 128-130, 2011.

7- KAWATA S.: Trans-Oral maxillectomy Radical Resection without Facial Incision Acta. Otolaryngol., 62 (6): 491504, 1966.

8- EDGE S.B. and COMPTON C.C.: The American joint committee on cancer: The 7 th edition of the AJCC cancer staging manual and the future of TNM. Ann. Surg. Oncol., 17 (6): 1471-4, 2010. 
9- El FATTAH H., ZAGHLOUL A., PEDEMONTE E. and ESCUIN T.: Pre-prosthetic surgical alterations in maxillectomy to enhance the prosthetic prognoses as part of rehabilitation of oral cancer patient. Med. Oral Patol. Oral Cir. Bucal., 17 (2): e262-70, 2012.

10- LIZARS J.: Excision of the upper jaw bones. Lancet, 1826, 2: 54-55. Quoted In: Sisson G.A., Toriumi D.M., Atiyah R.A.: Paranasal sinus malignancy: A comprehensive update. Laryngoscope, 99: 143-150, 1989.

11- WEBER-FERGUSSON: Operations of the upper jaw. In: A system of practical surgery. 2 nd ed. Philadilphia, Lea and Blanchard, 1845. Quoted in: Price J.C. and Koch W.M.: The midfacial degloving approach to the paranasal sinuses and skull base. In: Blitzer A., Lawson W, Friedman WH (eds): Surgery of the Paranasal Sinuses, 2 nd edition, W.B. Saunders, 19: 309-315, 1991.

12- BRISKIN K.B., ROSS D.A., SASAKI C.T. and O'MALLEY B.B.: Surgical Management of Carcinoma of the Nasal Vestibule, Nasal Cavity, and Paranasal Sinuses. In Harrison LB, Sessions R.B., Hong W.K. (eds): Head and Neck Cancer - A Multidisciplinary Approach, Lippincott-Raven, 25: 573-593, 1999.

13- CASSON P.R., BONNANO P.C. and CONVERSE J.M.:
The midfacial degloving procedure. Plast. Reconstr. Surg., 53: 102-103, 1974.

14- CONLEY J. and PRICE J.C.: Sublabial Approach to the Nasal and Nasopharyngeal Cavities. Am. J. Surg., 38 : 615-618, 1979.

15-MANIGLIA A.J. and PHILLIPS D.A.: Midfacial degloving for the management of nasal, sinus, and skull-base neoplasms. Otolaryngol. Clin. North. Am., 28: 1127-1143, 1995.

16- BROWNE J.D.: The midfacial degloving procedure for nasal, sinus, and nasopharyngeal tumors. Otolaryngol. Clin. North Am., 34: 1095-1201, 2001.

17- ZACHARIAH T. and NEELAKANDAN R.S.: Utility of the midface degloving approach for extended exposure in maxillary pathologies. Journal of Maxillofacial and Oral Surgery, 19: 217-224, 2019.

18- LIU Z., YU H., WANG D., WANG J., SUN X. and LIU J.: Combined transoral and endoscopic approach for total maxillectomy: A pioneering report. J. Neurol. Surg. B, 74: 160-165, 2013.

19- ADISMAN I.K.: Prosthesis serviceability for acquired jaw defects. Dent Clin. North Am., 34: 265-84, 1990.

\section{إستئصال الفلك العلوى عبر الفم}

$$
\begin{aligned}
& \text { الهدف من الدراسة: تقييم إستئصال الفك العلوى عبر الفم فو بعض مرضى سرطان الفك الطوى والجيب الأنفى الوجنى. } \\
& \text { أجريت الدراسة على مريض يعانون من ودم خيث بالجيب الأنفى الوجنى والفك العلوى بعد أخذ عينة من الودم بإستخدام منظار الأنف }
\end{aligned}
$$

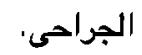

$$
\begin{aligned}
& \text { وقد تم إجراء عملية إستئمال الفلك العلوى والجيب الوجنى عبر القم وخضع المريض المتابعة لمدة خمس سنوات بعد إجراء العملية. }
\end{aligned}
$$

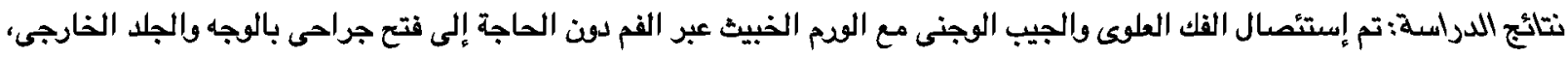

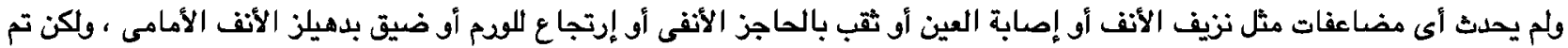

$$
\begin{aligned}
& \text { إكتشاف إرتجاع للورم الضبيث فى مريض واحد فقط. } \\
& \text { الخلاصة: إستئصال الفك العلوى والجيب الوجنى عبر الفم طريقة متاحة وأمنة فى بعض حالات مرضى سرطان الفك العلوى والجيب } \\
& \text { الوجنى، وينصح باستخداهها لهؤلاء المرضى. }
\end{aligned}
$$

